\title{
Lignocellulose as an insoluble fiber source in poultry nutrition: a review
}

\author{
llen Röhe ${ }^{*}$ and Jürgen Zentek
}

\begin{abstract}
Extensive research in recent years into the use of various fiber sources in poultry nutrition has led to the perception that dietary fiber is more than a simple diet diluent. Several studies showed that the feeding of insoluble fiber sources such as oat hulls, sunflower hulls or wood shavings may affect digestive physiology and function improving chickens health and growth performance. In this context, the effect of lignocellulose as an insoluble dietary fiber source is increasingly being investigated. Lignocellulose is a component of plant cell walls and consists mainly of the insoluble carbohydrate polymers cellulose and hemicelluloses as well as the phenolic polymer lignin. Lignocellulose is chemically and physicochemically different from other insoluble fiber sources and thus possibly has different effects on poultry compared to traditional fiber sources. Several studies investigated the effect of dietary lignocellulose on growth performance, nutrient digestibility, gastrointestinal tract development and intestinal microbiota in broilers and laying hens. Studies differed in terms of feed formulation and lignocellulose inclusion level as well as products of different suppliers were used. The results obtained are inconsistent; beneficial, indifferent or detrimental effects of feeding lignocellulose were observed, so that a final assessment of lignocellulose as a "novel" insoluble fiber source is difficult. This review article summarizes the results of studies in connection with the feeding of lignocellulose to poultry, compares them with those that have used other insoluble fiber sources and illuminates the possible mechanisms of action.
\end{abstract}

Keywords: Fiber, Growth performance, Gut health, Gut morphology, Lignocellulose, Microbiota, Nutrient digestibility, Poultry

\section{Introduction}

In recent years, there have been increasing scientific reports that dietary fiber can have a positive effect on animal health and productivity. Fiber as feed component in poultry nutrition has traditionally been given little consideration as it has only a low nutritional value from a chemical point of view. However, due to its unique physicochemical properties, several studies showed that insoluble fiber sources may affect digestive tract development and function resulting in improved chicken health and growth performance [1-4]. Feeding experiments were mainly carried out with insoluble fiber sources that arise as by-products during industrial

\footnotetext{
* Correspondence: ilen.roehe@fu-berlin.de

Department of Veterinary Medicine, Institute of Animal Nutrition, Freie Universität Berlin, 14195 Berlin, Germany
}

production such as oat hulls, sunflower hulls, soybean hulls, wheat bran or wood shavings. In the last decade, research has concentrated on the use of an "innovative" insoluble dietary fiber source, lignocellulose (LC). LC is a constituent of plant cell walls and thus the most abundant and bio-renewable biomass on earth [5]. Studies in farm and companion animals showed that dietary LC may have potential effects on digestive physiology and function [6-10]. This review gives a comprehensive overview of the effects of dietary LC in poultry. First, the physicochemical properties of LC are described and reference is made to methodological aspects of the incorporation of LC into feed, as this can have a decisive influence on the study results. Next, the results of studies on the effects of dietary LC on growth performance, nutrient digestibility, gastrointestinal tract development

(c) The Author(s). 2021, corrected publication 2021. Open Access This article is licensed under a Creative Commons Attribution 4.0 International License, which permits use, sharing, adaptation, distribution and reproduction in any medium or format, as long as you give appropriate credit to the original author(s) and the source, provide a link to the Creative Commons licence, and indicate if changes were made. The images or other third party material in this article are included in the article's Creative Commons licence, unless indicated otherwise in a credit line to the material. If material is not included in the article's Creative Commons licence and your intended use is not permitted by statutory regulation or exceeds the permitted use, you will need to obtain permission directly from the copyright holder. To view a copy of this licence, visit http://creativecommons.org/ licenses/by/4.0/. The Creative Commons Public Domain Dedication waiver (http://creativecommons.org/publicdomain/zero/1. 0/) applies to the data made available in this article, unless otherwise stated in a credit line to the data. 
and intestinal microbiota are summarized and compared with those observed in feeding experiments using other insoluble fiber sources. In particular, the potential mode of action of insoluble dietary fiber on the digestive physiology of chickens is discussed. In addition, some considerations regarding future research directions and methodological challenges are presented and discussed.

\section{Chemical composition and physicochemical properties of LC}

Dietary fiber comprises a significant part of plant feedstuffs and is chemically defined as the sum of non-starch polysaccharides (NSP) and lignin [11]. From a physiological point of view, dietary fiber comprises any polysaccharide and lignin that is not degraded by endogenous enzymes in the digestive tract, hence reaching the hindgut $[12,13]$. Different types of plants contain different amounts and chemical structures of fibers with varying physical properties [14]. Therefore, fiber sources differ in their content of soluble and insoluble NSP. Fiber sources with high levels of insoluble NSP are for example LC, oat hulls, sunflower hulls or wheat bran, while sugar beet pulp or apple pomace contain higher concentrations of soluble NSP [3, 13]. Lignocellulosic biomass refers to plant dry matter of different origin and is mainly composed of the carbohydrate polymers cellulose and hemicelluloses as well as the phenolic polymer lignin $[15,16]$. The proportional composition of carbohydrate and aromatic polymers of LC may vary depending on the type of lignocellulosic biomass used [17, 18]. LC applied in animal nutrition is usually derived from forest residues containing different proportions of hard and soft wood as well as bark. A recent study analyzed the chemical composition of three LC products used as fiber additives in animal feed [19]. Table 1 shows the chemical and physicochemical characteristics of these LC products compared to that of other insoluble fiber sources, in particular, oat hulls, sunflower hulls and wheat bran. The LC products showed a similar crude fiber content, but differences in the detergent fibers, which allow a rough assessment of the insoluble fractions of cellulose, hemicelluloses and lignin [13, 21]. Two products (LC2 and LC3) showed a similar cellulose, hemicelluloses and lignin content of $\sim 415, \sim 150$ and $\sim 330 \mathrm{~g} / \mathrm{kg}$ dry matter (DM), respectively, which are close to that reported by Zeitz et al. [22]. The LC1 product, however, contained significantly more lignin $(\sim 650 \mathrm{~g} / \mathrm{kg}$ $\mathrm{DM})$ and lower amounts of cellulose $(\sim 78 \mathrm{~g} / \mathrm{kg} \mathrm{DM})$. All three LC products comprised high proportions of more than $90 \%$ insoluble fibers and only small amounts of soluble fibers $[19,22]$. Similarly, oat hulls were mainly composed of insoluble dietary fiber [20] and contained primarily hemicelluloses and cellulose. Sunflower hulls showed slightly lower values for crude and detergent fiber, but the relative distribution of cellulose, hemicelluloses and lignin was similar when compared to LC2 and LC3. Sunflower hulls contained mostly insoluble fiber, but about twice as much soluble fiber compared to LC. Wheat bran had the lowest crude fiber content of all the fiber sources shown and was mainly composed of hemicelluloses. In addition, the proportion of soluble to insoluble dietary fibers in wheat bran was slightly higher compared to LC. With respect to the physicochemical properties, there is a positive correlation between dietary soluble fiber content and digesta viscosity in monogastric animals [13]. Due to the low proportion of soluble fibers such as pectins, insoluble dietary fiber sources have little effect on digesta viscosity $[3,14]$. Another important physicochemical feature of dietary fiber is their hydration capacity, which can be characterized by the swelling capacity, the water holding and binding capacity [13]. The hydration capacity of a dietary component affects the bulking effect of digesta [23], which in turn could have consequences on digesta retention time and nutrient digestibility [24]. LC showed higher

Table 1 Chemical and physicochemical characterization of different lignocellulose products in comparison with other insoluble fiber sources

\begin{tabular}{|c|c|c|c|c|c|c|c|}
\hline Item & Unit & $L C 1^{a, b}$ & $L C 2^{a, b}$ & $\mathrm{LC}^{\mathrm{a}, \mathrm{b}}$ & Oat hulls ${ }^{c}$ & Sunflower hulls ${ }^{a}$ & Wheat bran $^{\mathrm{a}}$ \\
\hline Crude fiber & $\mathrm{g} / \mathrm{kg} \mathrm{DM}$ & 579 & 559 & 561 & 302 & 535 & 145 \\
\hline Neutral detergent fiber (aNDFom) & & 926 & 919 & 874 & 750 & 843 & 585 \\
\hline Acid detergent fiber $\left(\mathrm{ADF}_{\mathrm{OM}}\right)$ & & 728 & 757 & 737 & 357 & 679 & 181 \\
\hline Acid detergent lignin ( $\left.A D L_{O M}\right)$ & & 650 & 329 & 335 & 40 & 255 & 70 \\
\hline Total dietary fiber & & 953 & 945 & 949 & 762 & 897 & 612 \\
\hline Insoluble dietary fiber & & 942 & 933 & 938 & 754 & 871 & 579 \\
\hline Soluble dietary fiber & & 11 & 13 & 12 & 8 & 27 & 34 \\
\hline Water holding capacity & $\mathrm{mL} / \mathrm{g} \mathrm{DM}$ & 5.21 & 4.63 & 7.43 & 3.9 & 4.35 & 5.51 \\
\hline Water binding capacity & & 7.29 & 6.30 & 6.35 & N/A & 5.88 & 5.09 \\
\hline Swelling property & $\%$ & 205 & 150 & 185 & $2.1^{\mathrm{d}}$ & 65 & 55 \\
\hline
\end{tabular}

according to Slama et al. [19]; ${ }^{\mathrm{b}}$ Information on the LC product used, if specified, is given in additional file $1 ;{ }^{\mathrm{c}}$ According to Jiménez-Moreno et al. [20]; ${ }^{\mathrm{d}}$ Indicated as $\mathrm{mL} / \mathrm{g}$ DM 
hydration capacities and significantly greater swelling properties compared to oat hulls, sunflower hulls and wheat bran $[19,20]$. Finally but yet importantly, the particle size of a fiber source is another key characteristic, which may influence digestive function [23]. After processing and fiber breakdown, LC is a powdery material with an average particle size of 80 to $300 \mu \mathrm{m}$ [22, 25]. This material can then be further processed, so that various LC products are commercially available, e.g. in powdery, crumbled or pelleted form. The particle size of other insoluble fiber sources is usually larger depending on the degree of grinding.

Inclusion of insoluble fiber sources in experimental diets In order to investigate the effect of dietary insoluble fiber in chickens, several feeding experiments were designed using different feed formulations. In principle, there are three different options to include fiber sources in diets, as displayed in Fig. 1. In "feed formulation 1", a "control" feed is compared with a "fiber dilution" diet. A "control" poultry diet usually consists of grains, protein sources, plant oils and a premix. The nutrient composition of the "control" diet should meet the nutrient recommendations for chicken diets. The treatment diet "fiber dilution" is based on the "control" diet, but supplemented with the fiber source of interest. As insoluble fiber sources, such as LC, cellulose or wood shavings, have a low nutritive value, the energy and nutrient content of the diet is diluted by the added fiber source. In "feed formulation 2", the same "control" diet is used, but the fiber containing diet is balanced to be isoenergetic and isonitrogenous. To achieve this, the "iso" diet must be formulated to have increased proportions of fat and protein at the expense of the carbohydrate source. Consequently, the "control" and the "iso" diet show remarkable differences in the feed-and nutrient composition, but show similar energy and protein concentrations. In "feed formulation 3", a "control sand" and a "fiber dilution" diet is used. The "control sand" diet is based on the "control" feed, but contains a certain percentage of an insoluble ash source, e.g. sand or sepolite. The "fiber dilution" diet is based on the "control sand" diet, but the insoluble ash source is substituted by the insoluble fiber source of interest. Thus, the feed composition is similar with the exception of the components sand

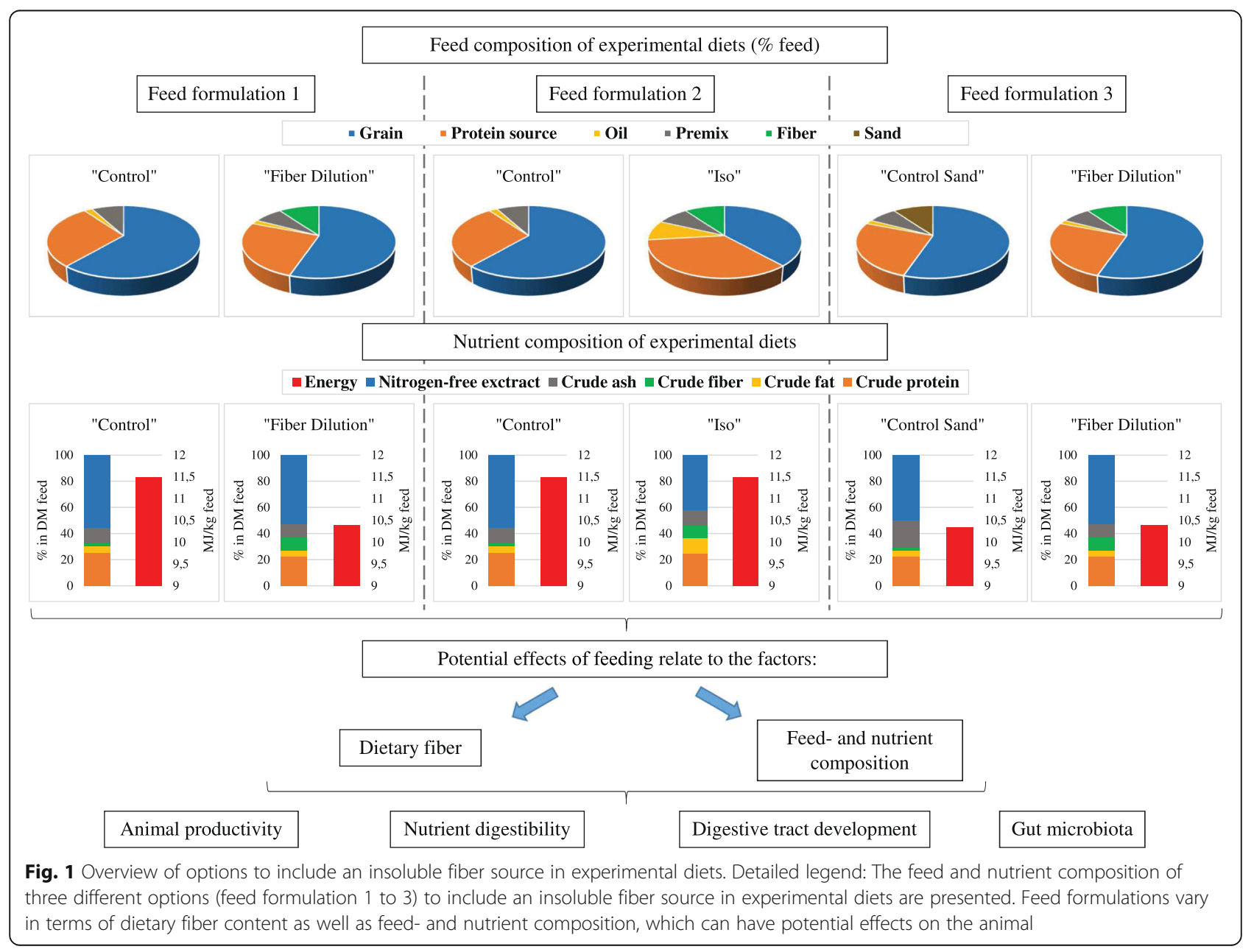


and fiber. As a result, the nutrient composition of both diets differs significantly only in terms of crude ash and crude fiber. In summary, the dietary inclusion of an insoluble fiber source is coupled with differences in the feedand nutrient composition of the experimental diets. Therefore, the effects of feeding these diets can be attributed to both, the factor "dietary fiber" and the factor "feed and nutrient composition" (Fig. 1). Thus, alterations in animal productivity, nutrient digestibility, digestive tract development or gut microbiota might be related to differences in dietary fiber and/or feed and nutrient composition. Reference is made to this issue in the respective sections of this review.

\section{Impact of dietary LC on productivity of chickens}

During the last decade, several studies examined the effect of feeding LC on the productivity of broilers (Table 2) and laying hens (Table 3). Productivity parameters include body weight (BW), average weight gain (AWG), average feed intake (AFI) or average daily feed intake (ADFI), feed conversion ratio (FCR), egg production (EP) and egg weight (EW). Studies differed in terms of feed formulation and LC inclusion level used. In most studies, dietary LC was supplemented on top of feed ("feed formulation 1", Fig. 1); only few used experimental diets based on "feed formulation 2 and 3" (Fig. 1). Commonly, lower dietary LC inclusion levels in the range of $0.05 \%$ to $2 \%$ have been used, while few experiments were performed using relatively high concentrations of dietary LC of $5 \%$ to $15 \%$.

Results obtained in broiler trials using relatively low dietary concentrations of LC are contradictory (Table 2). The feeding of diets supplemented with $0.25 \%$ to $2 \% \mathrm{LC}$ positively affected the FCR of broilers due to an increase in weight gain $[26,28]$. In contrast, broilers fed diets supplemented with $1 \%$ LC had an impaired FCR compared to those receiving the control diet [29]. However, several studies using similar LC inclusion levels showed no impact of dietary LC on broiler growth performance $[22,24,27]$. Results of a recent study demonstrated that dietary LC concentrations of $0.05 \%$ to $0.1 \%$ improved FCR of broilers, while the supplementation of $0.2 \%$ LC showed no effect on FCR [32]. Broilers fed 0.6\% LC, which was added at the expense of soybean meal and corn, showed higher BW after $42 \mathrm{~d}$ of feeding compared to those fed the control and $0.4 \%$ LC [30]. Interestingly, the feeding of the same LC concentration of $0.6 \%$, but which was added at the expense of soybean meal only, did not affect final BW of broilers [30] suggesting that the feed composition had a greater impact on BW development than the LC addition. Broilers fed diets diluted with relatively high concentrations of LC of $5 \%$ to $15 \%$ showed a marked decrease in average daily gain with increasing concentrations of dietary LC, while feed intake tended to increase with increasing concentrations of LC [31]. On the contrary, broiler productivity seems to be unaffected by relatively high dietary LC inclusion levels up to $10 \%$ when diets were composed to be isoenergetic and isonitrogenous [25, 39].

With respect to feeding experiments with commercial hybrid pullets and laying hens (Table 3), most studies showed that growth and laying performance were not affected by dietary LC inclusion levels of $0.8 \%$ to $2 \%$ [3335]. However, Sozcu and Ipek [36] demonstrated that the supplementation of $0.05 \%$ and $0.1 \%$ dietary LC increased BW, ADFI, EP, and EW of laying hens between 18 to 38 weeks of age compared to hens fed the control diet. A further increase in the dietary LC concentration to $0.2 \%$, however, led to a decrease in EP and EW [36]. In two other studies, the effect of dietary LC was investigated in broiler breeder hens [37] during the laying phase (43 to 55 weeks of age) and in dual purpose hens [38] during the growing (1-22 weeks of age) and laying period (23-52 weeks of age). Broiler breeder and dual purpose hens tended to overconsume feed leading to an increased body fat content, which in turn might be related to the observed lower productive efficiency [4042]. Thus, the hypothesis in both studies was that BW and body fat percentage of hens can be reduced by feeding a nutrient-reduced LC-containing diet and that this is accompanied with an improved reproductive performance $[37,38]$. The results showed that dietary LC reduced BW, body fat content [38] and abdominal fat weight of hens [37], which was directly associated with an improved laying performance.

In principle, due to the use of different feed formulations and inclusion levels, it is difficult to make a conclusive statement about the effect of LC on chicken productivity. Few studies showed that similar insoluble fiber sources such as cellulose or wood shavings could have a positive impact on broiler growth performance [43, 44]. It was suggested that a combination of improved gut function and enhanced nutrient digestibility was responsible for observed beneficial effects [43, 44]. With regard to dietary LC and lower inclusion levels, it was also hypothesized that digestive physiology and nutrient digestibility might be affected leading to improved growth performance $[26,28,30]$. However, data on the effects of dietary LC on digestive tract development and nutrient digestibility were inconclusive, as described later. Studies generally showed that animal productivity was impaired when diets were supplemented with higher dietary LC concentrations. This observation is explained by the fact that the energy- and nutrient content of diets was considerably reduced by the LC inclusion ("feed formulation 1", Fig. 1) resulting in a lower energy and nutrient intake of chickens impairing growth performance. However, animal productivity seems to be not affected 
Table 2 Impact of dietary lignocellulose on broiler growth performance

\begin{tabular}{|c|c|c|c|c|c|c|c|}
\hline Feed $^{1}$ & Age, $d$ & LC Inclusion ${ }^{2}, \%$ & Final $\mathrm{BW}^{3}, \mathbf{g}$ & $\mathrm{AFI}^{4}, \mathrm{~g}$ & $A W G^{5}, g$ & FCR & Reference \\
\hline \multirow[t]{8}{*}{1} & 21 & 0 & & 1057 & 582 & $1.81^{\mathrm{a}}$ & [26] \\
\hline & & 0.25 & & 1049 & 596 & $1.75^{\mathrm{a}}$ & \\
\hline & & 0.50 & & 1033 & 615 & $1.67^{\mathrm{b}}$ & \\
\hline & & 0.75 & & 1030 & 618 & $1.66^{\mathrm{b}}$ & \\
\hline & $1-42$ & 0 & & 4016 & $1915^{b}$ & $2.1^{\mathrm{a}}$ & \\
\hline & & 0.25 & & 4086 & $2084^{a}$ & $1.96^{\mathrm{b}}$ & \\
\hline & & 0.50 & & 4030 & $2073^{\mathrm{a}}$ & $1.94^{\mathrm{b}}$ & \\
\hline & & 0.75 & & 4156 & $2147^{a}$ & $1.93^{b}$ & \\
\hline \multirow[t]{4}{*}{1} & $1-42$ & 0 & 2422 & & 80.2 & 1.865 & [27] \\
\hline & & 0.25 & 2423 & & 80.7 & 1.876 & \\
\hline & & 0.5 & 2436 & & 81.0 & 1.854 & \\
\hline & & 1.0 & 2429 & & 81.0 & 1.875 & \\
\hline \multirow[t]{6}{*}{3} & 7-14 & 0 & & 161 & $69.2^{\mathrm{b}}$ & $2.33^{\mathrm{a}}$ & [28] \\
\hline & & 1 & & 150 & $78.0^{\mathrm{a}}$ & $1.92^{b}$ & \\
\hline & & 2 & & 150 & $71.7^{\mathrm{b}}$ & $2.09^{\mathrm{ab}}$ & \\
\hline & $14-21$ & 0 & & 326 & 128 & $2.55^{\mathrm{a}}$ & \\
\hline & & 1 & & 299 & 152 & $1.98^{\mathrm{b}}$ & \\
\hline & & 2 & & 291 & 145 & $2.03^{b}$ & \\
\hline \multirow[t]{6}{*}{1} & $1-10$ & 0 & & 294 & 277 & 1.059 & [24] \\
\hline & & 1 & & 292 & 271 & 1.078 & \\
\hline & & 2 & & 294 & 276 & 1.065 & \\
\hline & $1-35$ & 0 & & 3770 & 2741 & 1.376 & \\
\hline & & 1 & & 3778 & 2716 & 1.392 & \\
\hline & & 2 & & 3797 & 2719 & 1.397 & \\
\hline \multirow[t]{2}{*}{1} & $1-21$ & 0 & & 1085 & 860 & $1.265^{b}$ & [29] \\
\hline & & 1 & & 1054 & 815 & $1.297^{\mathrm{a}}$ & \\
\hline \multirow[t]{12}{*}{1} & $1-7$ & 0 & & $129^{b}$ & $121^{c}$ & $1.07^{\mathrm{a}}$ & [30] \\
\hline & & 0.4 & & $132^{\mathrm{b}}$ & $128^{\mathrm{ab}}$ & $1.03^{b}$ & \\
\hline & & $0.6^{6}$ & & $140^{\mathrm{a}}$ & $132^{\mathrm{a}}$ & $1.06^{\mathrm{a}}$ & \\
\hline & & $0.6^{7}$ & & $130^{\mathrm{b}}$ & $126^{\mathrm{bc}}$ & $1.03^{b}$ & \\
\hline & $14-21$ & 0 & & 590 & $396^{\mathrm{b}}$ & 1.49 & \\
\hline & & 0.4 & & 588 & $402^{b}$ & 1.46 & \\
\hline & & $0.6^{6}$ & & 621 & $432^{\mathrm{a}}$ & 1.44 & \\
\hline & & $0.6^{7}$ & & 594 & $403^{b}$ & 1.47 & \\
\hline & $28-42$ & 0 & $2428^{b}$ & $2295^{a}$ & 1284 & $1.79^{\mathrm{a}}$ & \\
\hline & & 0.4 & $2423^{b}$ & $2084^{b}$ & 1245 & $1.67^{b}$ & \\
\hline & & $0.6^{6}$ & $2611^{a}$ & $2186^{c}$ & 1310 & $1.67^{\mathrm{b}}$ & \\
\hline & & $0.6^{7}$ & $2495^{b}$ & $2182^{\mathrm{bc}}$ & 1292 & $1.69^{b}$ & \\
\hline \multirow[t]{3}{*}{1} & $1-35$ & 0 & 2431 & 3459 & 2390 & 1.42 & [22] \\
\hline & & $0.8^{8}$ & 2370 & 3386 & 2329 & 1.42 & \\
\hline & & $0.8^{8}$ & 2490 & 3452 & 2448 & 1.39 & \\
\hline \multirow[t]{3}{*}{1} & $13-25$ & 0 & $1080^{\mathrm{a}}$ & $0.250^{9}$ & $0.173^{10}$ & & [31] \\
\hline & & 5 & $995^{\mathrm{ab}}$ & $0.258^{9}$ & $0.164^{10}$ & & \\
\hline & & 10 & $928^{b c}$ & $0.258^{9}$ & $0.153^{10}$ & & \\
\hline
\end{tabular}


Table 2 Impact of dietary lignocellulose on broiler growth performance (Continued)

\begin{tabular}{|c|c|c|c|c|c|c|c|}
\hline Feed $^{1}$ & Age, $d$ & LC Inclusion ${ }^{2}, \%$ & Final $\mathrm{BW}^{3}, \mathrm{~g}$ & $\mathrm{AFI}^{4}, \mathrm{~g}$ & $A W G^{5}, g$ & FCR & Reference \\
\hline & & 15 & $836^{c}$ & $0.270^{9}$ & $0.149^{10}$ & & \\
\hline \multirow[t]{4}{*}{1} & $1-35$ & 0 & $2154^{\mathrm{bc}}$ & $1293^{\mathrm{ab}}$ & 650 & $1.58^{\mathrm{a}, 11}$ & [32] \\
\hline & & 0.05 & $2201^{b}$ & $1266^{\mathrm{bc}}$ & 631 & $1.51^{b, 11}$ & \\
\hline & & 0.1 & $2305^{a}$ & $1314^{a}$ & 667 & $1.50^{b, 11}$ & \\
\hline & & 0.2 & $2142^{c}$ & $1266^{c}$ & 626 & $1.55^{\mathrm{ab}, 11}$ & \\
\hline \multirow[t]{3}{*}{2} & 70-91 & 0.8 & 1658 & 899 & 454 & 1.98 & [25] \\
\hline & & 5 & 1639 & 992 & 467 & 2.15 & \\
\hline & & 10 & 1618 & 905 & 432 & 2.10 & \\
\hline
\end{tabular}

${ }^{1}$ Feed formulation according to Fig. $1 ;{ }^{2}$ Information on the LC product used, if specified, is given in additional file $1 ;{ }^{3} \mathrm{BW}=$ body weight; ${ }^{4} \mathrm{AFI}=$ average feed intake; ${ }^{5}$ AWG = average weight gain; ${ }^{6} \mathrm{LC}$ was included in the diet at the expense of $0.3 \%$ soybean meal and $0.3 \%$ maize; ${ }^{7} \mathrm{LC}$ was included in the diet at the expense of $0.6 \%$ soybean meal; ${ }^{8}$ Two different lignocellulose products were compared; ${ }^{9}$ Indicated as average daily feed intake in (g/d)/BW; ${ }^{10}$ Indicated as average daily gain in $\mathrm{g} / \mathrm{d} / \mathrm{BW} ;{ }^{11}$ Indicated as $\mathrm{g}$ weight gain/g feed consumption; ${ }^{\mathrm{a}, \mathrm{b}, \mathrm{c}}$ Means with different superscripts are significantly different

when higher concentrations of LC are included in isoenergetic and isonitrogenious diets ("feed formulation 2", Fig. 1). This phenomenon is already known from former studies, which showed that the crude fiber concentration did not influence growth performance unless it affected the energy content in the diets [45-47]. Chickens usually have the ability to cover their metabolic energy requirement to a certain degree by increasing or decreasing the feed consumption $[48,49]$. Chickens receiving diets diluted by sand or oat hulls up to $20 \%$ showed an increased feed intake resulted in a similar energy intake and average daily gain in comparison to those receiving an undiluted control diet $[49,50]$. With respect to higher dietary inclusion levels of powdery LC, this

Table 3 Impact of dietary lignocellulose on hen productivity

\begin{tabular}{|c|c|c|c|c|c|c|c|c|}
\hline Species & Feed $^{1}$ & Age, week & LC inclusion ${ }^{2}, \%$ & Final $\mathrm{BW}^{3}, \mathrm{~g}$ & $\mathrm{ADFI}^{4}, \mathrm{~g}$ & $E P^{5}, \%$ & $\mathrm{EW}^{6}, \mathrm{~g}$ & Reference \\
\hline \multirow[t]{4}{*}{ Laying hen } & 1 & 30 & 0 & & 126 & 94.7 & 65 & [33] \\
\hline & & & 1 & & 131 & 95.5 & 66 & \\
\hline & & 36 & 0 & & 144 & 93.4 & 66 & \\
\hline & & & 1 & & 144 & 93.7 & 66 & \\
\hline \multirow[t]{2}{*}{ Pullet } & 1 & $8-18$ & 0 & 1580 & & & & {$[34]$} \\
\hline & & & 1 & 1678 & & & & \\
\hline \multirow[t]{2}{*}{ Laying hen } & 1 & $22-31$ & 0 & 1902 & & & & [34] \\
\hline & & & 0.8 & 1919 & & & & \\
\hline \multirow[t]{3}{*}{ Pullet } & 1 & $1-8$ & 0 & 766 & 50.6 & & & [35] \\
\hline & & & 1 & 776 & 52.4 & & & \\
\hline & & & 2 & 764 & 51.6 & & & \\
\hline \multirow[t]{4}{*}{ Laying hen } & 1 & $18-38$ & 0 & $1655^{\mathrm{c}}$ & $96.3^{b}$ & $78.0^{c}$ & $55.3^{c}$ & {$[36]$} \\
\hline & & & 0.05 & $1693^{b}$ & $98.0^{\mathrm{a}}$ & $80.8^{b}$ & $56.4^{b}$ & \\
\hline & & & 0.1 & $1719^{\mathrm{a}}$ & $99.2^{\mathrm{a}}$ & $81.8^{\mathrm{a}}$ & $57.3^{\mathrm{a}}$ & \\
\hline & & & 0.2 & $1636^{c}$ & $95.4^{b}$ & $78.6^{d}$ & $54.4^{d}$ & \\
\hline \multirow[t]{2}{*}{ Broiler breeder hen } & 3 & $43-55$ & 0 & $\sim 4500^{\mathrm{a} 7}$ & $174^{\mathrm{a}}$ & $56.9^{b}$ & 69.9 & [37] \\
\hline & & & 3 & $\sim 4300^{\mathrm{b} 7}$ & $172^{b}$ & $62.9^{\mathrm{a}}$ & 69.2 & \\
\hline \multirow[t]{4}{*}{ Dual purpose hen } & 1 & $1-22$ & 0 & $1835^{\mathrm{a}}$ & 61.1 & & & {$[38]$} \\
\hline & & & 10 & $1694^{b}$ & 61.2 & & & \\
\hline & & $23-52$ & 0 & $1996^{\mathrm{a}}$ & $101^{b}$ & $63.4^{b}$ & $60.6^{a}$ & \\
\hline & & & 10 & $1791^{b}$ & $107^{\mathrm{a}}$ & $72.4^{\mathrm{a}}$ & $58.0^{\mathrm{b}}$ & \\
\hline
\end{tabular}

${ }^{1}$ Feed formulation according to Fig. $1 ;{ }^{2}$ Information on the LC product used, if specified, is given in additional file $1 ;{ }^{3} \mathrm{BW}=$ body weight; ${ }^{4} \mathrm{ADFI}=$ average daily feed intake; ${ }^{5} \mathrm{EP}=$ egg production; ${ }^{6} \mathrm{EW}=$ egg weight; ${ }^{7}$ Data on BW are estimated because they were taken from a figure; ${ }^{\mathrm{a}, \mathrm{b}, \mathrm{c}}$ Means with different superscripts are significantly different 
regulatory mechanism seem to be partially restricted [31, 38], which might be attributed to the physical form of fine LC fibers and its physical bulking effect [37, 38]. Accordingly, the use of higher concentrations of powdery $\mathrm{LC}$ in feed for broiler breeder and dual purpose hens, might be a reasonable dietary strategy to control feed intake and weight gain ensuring an optimal productive performance.

\section{Impact of dietary LC on the nutrient digestibility in chickens}

Data regarding the effect of dietary LC on nutrient digestibility in chickens are scarce displaying no clear picture. A direct comparison of results is difficult: on the one hand, diets differed in their feed composition and nutrient content; on the other hand, different dietary LC concentrations were used. The feeding of isoenergetic and isonitrogenous diets containing $0.8 \%$ LC increased the true digestibility of protein as well as the apparent and true dietary amino acid digestibility in roosters compared to those fed the control diet [51]. Similarly, the same authors observed that the apparent protein digestibility was increased by $5.5 \%$ in broilers fed $0.8 \%$ dietary LC compared to those receiving the control diet [52]. In contrast, the supplementation of $1 \%$ or $2 \%$ dietary LC did not affect protein and gross energy digestibility in broilers [24, 29]. Feeding of isoenergetic and isonitrogenous diets with higher LC inclusion levels of 5\% and $10 \%$ led to a decrease in the apparent ileal digestibility of crude protein and apparent excreta digestibility of organic matter and gross energy while the total tract digestibility of ether extract was not affected [25]. The apparent ileal fat digestibility and total tract digestibility of total fatty acids in broilers was also not influenced by the supplementation of $0.25 \%$ and $0.5 \%$ LC while the feeding of $1 \%$ LC resulted in an increased apparent fat digestibility [53].

If dietary LC has an impact on the digestibility of nutrients, either beneficial or detrimental, the question arises as to how LC might affect the digestive physiology of chickens. Regarding the beneficial effects, it is well known that the feeding of structural components, such as coarse fiber particles, may stimulate digestive function, which is associated with an improved nutrient digestibility [23, 54]. LC consists of very small fiber particles and thus it remains unclear whether dietary LC may affect the digestive physiology and thus the nutrient digestibility in chickens, as discussed later. Another positive effect of feeding LC might be related to the fat digestibility. Jiménez-Moreno et al. [55] speculated that dietary cellulose might have an effect on micelle formation and lipid absorption, enhancing bile acids recycling and fat absorption. Further research is needed in order to evaluate this hypothesis. With respect to the potential adverse effects, it was assumed that dietary LC might have an abrasive effect on the intestinal mucosa [27, 30], thus enhancing endogenous amino acid losses. In this regard, Kluth and Rodehutscord [56] showed that the feeding of increasing concentrations of cellulose up to $8 \%$ significantly elevated the inevitable losses of crude protein and amino acids in broilers. Whether this observation also applies to the feeding of increasing concentrations of LC requires further clarification. In summary, based on the studies carried out so far, no statement can be made about whether LC has an impact on nutrient digestibility in chickens.

\section{Impact of dietary LC on gastrointestinal tract development, intestinal morphology and excreta characteristics of chickens}

Few studies exist evaluating the effect of dietary LC on the gastrointestinal tract development and digestive physiology of broilers and laying hens. Investigations were focused on the gastrointestinal gross morphology, the intestinal histomorphology, and digesta as well as excreta characteristics.

\section{Effect on gizzard development and function}

In broilers, most studies showed that the feeding of lower dietary LC concentrations up to $2 \%$ did not affect the relative weight of the gizzard [22, 24, 28-30]. However, feeding of isoenergetic and isonitrogenous diets containing 5\% LC resulted in an increased gizzard weight of slow growing broilers [39]. Similarly, the relative gizzard weight was affected by feeding LC in laying hens and pullets [34]. Pullets fed 1\% LC over a period of 10 weeks showed increased relative weights of the gizzard. Moreover, laying hens, aged 31 weeks, developed heavier gizzards when fed diets diluted with $0.8 \%$ LC after 12 weeks of feeding [34]. Interestingly, these effects were not observed in chickens that received these diets for a shorter period, suggesting a time-dependent effect of LC. Studies in quails also showed that the feeding of isoenergetic and isonitrogenous diets containing 3\% LC increased the relative gizzard weights [57]. Few studies investigated the effect of dietary $\mathrm{LC}$ on gizzard $\mathrm{pH}$ showing conflicting results. The feeding of diets supplemented with $0.4 \%$ and $0.6 \%$ LC decreased the gizzard $\mathrm{pH}$ of broilers [30], while the feeding of $0.8 \%, 1 \%$ and $2 \%$ dietary LC had no impact on gizzard $\mathrm{pH}[22,24]$. Broilers fed diets containing $0.05 \%$ to $0.2 \%$ LC showed also a similar gizzard $\mathrm{pH}$ compared to those fed the control diet [32].

In general, coarsely ground fiber sources such as oat, soybean and pea hulls, or wood shavings, containing primarily insoluble NSP, are known to increase gizzard size and weight $[43,58,59]$. An increased gizzard weight might be an indicator of enhanced gizzard function [23, 
54, 60, 61]. Several feeding experiments using different coarsely ground fiber sources showed that an increased gizzard weight was accompanied with a lower gizzard $\mathrm{pH}$ [59, 61-63] suggesting an enhanced proventricular secretion of hydrochloric acid. Moreover, an increased gizzard activity is related to an increased gastrointestinal reflux and pancreatic enzyme secretion [64-67]. Furthermore, the feed passage rate might be affected by feeding structural fiber components improving nutrient digestibility and growth performance of chickens. In this regard, it is generally accepted that the feeding of coarsely ground, insoluble fibers increases the feed passage rate [23]. However, in poultry it is suggested that the feeding of moderate amounts of structural dietary fiber reduces the digesta transit time, as fiber particles may accumulate in the gizzard $[23,58]$. A recent study proved that digesta transit time of broilers was not affected by feeding diets containing finely ground LC or oat hulls [29]. The question arises whether the fiber inclusion itself, the particle size of the fiber source or a combination of both factors are responsible for observed effects on gizzard development and digestive function. In this regard, Jiménez-Moreno et al. [55] investigated the impact of type and particle size of dietary fiber on gizzard weight of broilers (Fig. 2). Diets contained different fiber sources, in particular cellulose, oat hulls and sugar beet pulp at inclusion levels of 3\%. Furthermore, diets differed in terms of particle size distribution indicated by different geometric mean diameters (GMD). Results indicated that broilers fed diets showing the highest GMD, namely coarsely ground oat hulls and sugar beet pulp, developed the greatest gizzard weights, while broilers fed diets having the lowest GMD, cellulose and finely ground sugar beet pulp, showed the lowest gizzard weights (Fig. 2). It was concluded that dietary cellulose did not stimulate gizzard function due its lack of physical structure [55]. Thus, it seems obvious that particle size of the fiber source, rather than fiber inclusion itself, is the determining factor that stimulates gizzard development. In this regard, it has been suggested that feed particles should be at least larger than $1 \mathrm{~mm}$ to enhance gizzard development [54,68]. Based on this, it can therefore be assumed that fine-fiber LC, similar to cellulose, has little effect on gizzard development and function. In this context, it would be interesting to investigate whether the physical form or the macrostructure of LC might have an impact on gizzard development. Therefore, future studies should investigate the effects of the physical form of $\mathrm{LC}$ and that of the overall feed structure on digestive physiology in chickens.

\section{Effect on the intestinal gross morphology}

Only few studies investigated the impact of dietary LC on the development of the small and large intestine, but most of them showed no effect of LC feeding on the intestinal gross morphology. In broilers, the feeding of relatively low dietary LC inclusion levels of $0.4 \%$ and $0.6 \%$ did not affect the relative weight of the intestine [30]. In agreement with this, broilers fed diets supplemented with $1 \%$ LC had similar relative duodenal, jejunal and cecal weights compared to those fed the control diets [29]. Relative lengths of small intestinal segments were also comparable between broilers fed $0.25 \%$ to $1 \%$ dietary LC and those offered the control diet [69]. Similarly, the absolute length of the small intestine and cecum of broilers was not influenced by feeding isoenergetic and isonitrogenous diets containing $2 \%$ and $4 \%$ LC. In another study, the feeding of isoenergetic and isonitrogenous diets containing 3\% LC increased the relative weight of the jejunum and ileum of quails [57]. Pullets fed $1 \%$ LC over a period of 10 weeks

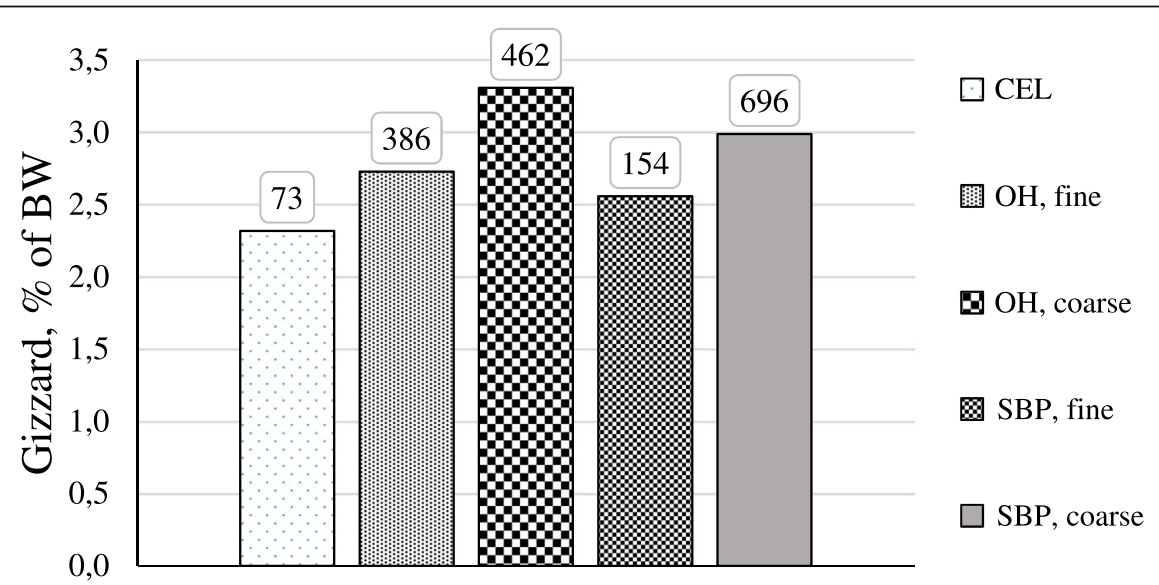

Fig. 2 Impact of dietary fiber and particle size on the gizzard weight of broilers. Detailed legend: Effect of type and particle size of dietary fiber on the relative gizzard weight of broilers according to Jiménez-Moreno et al. [55]; CEL = cellulose-fed broilers; OH = oat hulls-fed broilers; SBP = sugar beet pulp-fed broilers; the geometric mean diameter of diets is indicated above the respective bar 
showed comparable relative weights of the small intestine compared to those fed the control diet [34]. The feeding of diets supplemented with LC concentrations of $1 \%$ to $2 \%$ also showed no impact on the absolute cecal weight and length of laying hens [35] nor on the relative cecal weight of pullets [34]. The feeding of isoenergetic and isonitrogenous diets containing higher concentrations of LC up to $5 \%$ also had no impact on the absolute length of the small intestine and cecum of slow growing broilers [39]. In contrast, the feeding of energy- and nutrient reduced diets containing $10 \% \mathrm{LC}$, led, in relation to the BW, to increased weights of the small and large intestine [70].

Reasons for alterations in length or weight of intestinal organs due to feeding insoluble fiber sources are not fully understood. In general, it is supposed that an increase in the intestinal size and length but also an enlargement of the intestinal mucosa contributes to a higher intestinal weight [71]. Several studies demonstrated that chickens fed different insoluble fiber sources at varying inclusion levels showed increased relative digestive tract weights $[63,70,72]$ implying a fiber-related effect on intestinal organ development [63, 72]. However, in those studies dietary fiber inclusion also led to a decrease of the chicken's BW [63, 70, 72]. Therefore, the hypothesis that dietary fiber influenced organ weight development in those chickens is not valid as data on intestinal weight and length are related to the BW. Only considering studies in which chickens had similar empty $B W$, results on the effect of fiber on intestinal tract development are conflicting. On the one hand, it has been reported that feeding of isoenergetic and isonitrogenous diets containing 3\% insoluble fiber sources, such as oat and soybean hulls, increased the digestive tract weight of broilers $[59,61,73,74]$. On the other hand, the feeding of isoenergetic and isonitrogenous diets containing 3\% oat hulls, soybean hulls or cellulose did not affect the relative weight of intestinal organs $[55,75,76]$. Similarly, the feeding of diets, supplemented with $10 \%$ oat hulls or cellulose, did also not affect the relative weight of intestine of broilers [77, 78]. Regarding possible fiber-effects on intestinal tract development, it was suggested that an enlargement of the digestive tract might be a consequence of physical distension caused by luminal swelling of the ingested fiber sources [59, 63, 72]. Further research is needed in order to clarify whether and why dietary insoluble fiber may have an impact on gut gross morphology.

\section{Effects on the intestinal mucosal development}

Few studies showed that dietary LC might affect the morphology of the intestinal mucosa of chickens. Sarikahn et al. [26] showed that ileal villus height and villus height to crypt depth ratio were increased in broilers fed diets containing $0.25 \%, 0.5 \%$ and $0.75 \%$ LC. Similarly, broilers receiving diets supplemented with up to $2 \%$ LC had an increased jejunal villus height, villus apparent surface area and villus height to crypt depth ratio compared to those fed the control diet [32]. In contrast, duodenal and jejunal villus height and crypt depth were reduced in broilers fed diets supplemented with $0.5 \%$ LC while the inclusion of $1 \%$ LC showed no effect on villus morphology [69]. Interestingly, a different observation was made in the ileum of those chickens as increasing concentrations of dietary LC led to an increase in villus height and crypt depth [69]. The feeding of $0.6 \%$ LC, which was included in the diet at the expense of soybean meal, resulted in an increased villus height and width as well as crypt depth in the duodenum, jejunum and ileum of broilers [30]. However, the same inclusion level of $0.6 \%$ dietary LC, supplemented at the expense of $0.3 \%$ soybean meal and $0.3 \%$ corn, did not affect duodenal and jejunal villus height and villus width of broilers [30] implying that intestinal mucosal development was influenced by feed composition rather than dietary LC inclusion. Abdollahi et al. [29] showed that the supplementation of $1 \%$ dietary LC had no impact on histomorphological parameters in the duodenum and jejunum of broilers. In laying hens, the feeding of $0.05 \%$ and $0.1 \%$ dietary LC increased jejunal villus height and width, villus apparent surface area and villus height to crypt depth ratio, while a further increase in dietary LC concentration of $0.2 \%$ decreased observed histomorphological parameters [36]. Dual purpose hens fed diets supplemented with $10 \%$ LC showed an enhanced mucosal development of the colorectum indicated by a greater villus area and a higher villus and crypt mucosal enlargement factor [70]. Interestingly, the colorectal villus surface was negatively correlated with the short chain fatty acid (SCFA) concentration in the cecum of hens [70]. Another study showed that the feeding of 3\% dietary LC included in isoenergetic and isonitrogenous diets increased the villus height and villus height to crypt depth ratio in the jejunum and ileum of quails [57].

An enlargement of the intestinal surface area due to longer or increased numbers of intestinal villi is generally associated with an increased intestinal nutrient absorption $[79,80]$ and thus an improved nutrient utilization. However, the development of the intestinal microarchitecture strongly depends, among other things, on the concentration of enteral nutrients and thus on the nutrient content of the diet $[81,82]$. It has been suggested that chickens fed high-fiber diets suffer from a nutrient deficiency and thus try to enhance nutrient and bacterial metabolite absorption by increasing the mucosal surface area $[70,82,83]$. Thus, it has to be emphasized that both the dietary nutrient content and/or the fiber inclusion might affect the mucosal development of 
the intestine (Fig. 1). However, effects on intestinal mucosal development were also observed in studies using isoenergetic and isonitrogenous diets or lower dietary fiber inclusion levels [26, 30,74], so that similar enteral nutrient concentrations can be expected. The potential mode of action of dietary insoluble fiber on intestinal mucosal development in chickens is still unknown. Whether specific chemical and physicochemical properties of the fiber source or changes in the intestinal microbiota due to fiber feeding could be responsible requires further clarification.

\section{Effects on excreta quality}

Studies in broilers indicated that dietary LC inclusion might have a positive effect on litter quality. Litter moisture content was lower in broilers fed diets supplemented with $0.6 \%, 0.8 \%, 1 \%$, and $2 \%$ LC compared to litter of control-fed broilers [24, 30, 52]. Similarly, litter moisture content was also reduced in quails fed 3\% dietary LC [57]. The litter DM content usually correlates with the DM content of the excreta. Consistent with the latter, laying hens fed 10\% LC for 52 weeks had a higher excreta DM content at 10, 17 and 22 weeks of age compared to those fed the control diet [70]. However, studies in broilers showed no impact of dietary LC on excreta scoring or excreta DM [22, 25].

In comparison with other insoluble fiber sources, LC has a moderate to high water holding capacity [19]. It has been speculated that the water holding capacity and the digesta retention time might be increased in LC fed chickens resulting in increased luminal water absorption and higher excreta DM content [24]. In addition to the hydration capacity, digesta- and excreta DM might be also affected by the particle size of the fed fiber source. Excreta score was improved in broilers fed coarsely ground wood shavings at a ratio of $6: 100(\mathrm{w} / \mathrm{w})$, while finely ground cellulose- and control-fed broilers showed comparable excreta scores [43]. Authors speculated that coarsely ground fibers might hold larger amounts of water reducing the solubilisation of NSP than finely ground fiber particles [43]. Further research is needed in order to clarify whether and why insoluble fiber sources might reduce excreta DM and thus improve litter quality.

\section{Impact of dietary LC on the gut microbiota}

It is well known that dietary fiber can modulate the gut microbiota in humans and animals, which in turn might have consequences on the intestinal health [84, 85]. Thus, few studies evaluated the impact of dietary LC on the intestinal microbiota in chickens. Alterations in the microbial composition can be accompanied with changes in the production of bacterial metabolites; vice versa, shifts of the intestinal bacterial metabolite profile are a clear indicator for a modification of the composition and activity of intestinal bacteria. Therefore, investigations were focused on both, bacteria residing in the avian intestinal tract and the concentration of intestinal bacterial metabolites. Table 4 shows the impact of dietary LC on the concentration of SCFA in the intestine of chickens. In general, results are conflicting, which may be explained by differences in the used study design, in particular regarding the used feed formulation, LC inclusion level and LC product.

Few studies used the same LC product, but different LC inclusion levels and feed formulations $[25,27,30$, 70]. The feeding of diets supplemented with $\mathrm{LC}$ at relatively low inclusion levels of $0.25 \%$ to $0.6 \%$ reduced counts of Escherichia coli and Clostridium perfringens and increased those of Bifidobacterium spp. and lactic acid bacteria in the ileum and cecum of broilers [30]. Similarly, ileal counts of Lactobacillus spp. as well as ileal and cecal counts of Bifidobacterium spp. were elevated in broilers fed diets supplemented with $0.25 \%$, $0.5 \%$ and $1 \%$ LC [27]. Ileal and cecal counts of Escherichia coli and Clostridium spp. were also reduced in broilers receiving $0.25 \%$ and $0.5 \%$ dietary LC [27]. In the same experiment, however, the intestinal SCFA profile was generally not affected by LC feeding (Table 4), with the exception of broilers receiving $0.5 \% \mathrm{LC}$, which showed increased total SCFA concentrations in the ileum and cecum [27]. Two further studies evaluated the effect of relatively high concentrations of dietary LC on bacterial composition and metabolites $[25,70]$. The feeding of diets diluted with $10 \%$ dietary LC had generally no impact on cecal microbial composition in dual pupose hens, but reduced the cecal concentration of SCFAs and ammonia [70]. Similarly, cecal bacterial metabolites were reduced in broilers fed isoenergetic and isonitrogenous diets containing 10\% LC [25]. Moreover, increasing concentrations of dietary LC decreased counts of Escherichia/Hafnia/Shigella [25]. Four recent studies using a potential more fermentable LC product also displayed conflicting results regarding the effect of dietary LC on the gut microbiota in broilers and laying hens $[22,24,35,86]$. The feeding of isoenergetic, isonitrogenous diets containing $2 \%$ and $4 \%$ LC increased the cecal microbial diversity and the abundance of butyrateproducing bacteria in free-range chickens, while the luminal concentration of butyrate, acetate and propionate was not affected [86]. In contrast, broilers and laying hens fed diets which were supplemented with $0.8 \%$ and $1 \%$ LC, showed no alterations in the overall cecal microbial diversity [22, 35]. Sun at al [35]. showed that the feeding of $1 \%$ LC increased the relative abundance of lactate- and butyrate-producing bacteria in the cecum of laying hens, which was accompanied with higher concentrations of cecal SCFAs. In contrast, the total amount 
Table 4 Impact of dietary lignocellulose on the concentration of intestinal short chain fatty acids (SCFA)

\begin{tabular}{|c|c|c|c|c|c|c|c|c|c|}
\hline Species & Feed $^{1}$ & Part $^{2}$ & LC inclusion ${ }^{3}, \%$ & Unit & Total SCFA & Acetate & Propionate & Butyrate & Reference \\
\hline \multirow[t]{4}{*}{ Broiler } & 1 & lle & 0 & $\mu \mathrm{mol} / \mathrm{g}$ & $53^{b}$ & $9.16^{\mathrm{bc}}$ & $3.78^{b}$ & 4.54 & [27] \\
\hline & & & 0.25 & & $61.1^{\mathrm{ab}}$ & $7.16^{\mathrm{C}}$ & $9.72^{\mathrm{ab}}$ & 5.22 & \\
\hline & & & 0.5 & & $86.3^{\mathrm{a}}$ & $20^{\mathrm{a}}$ & $17.4^{\mathrm{a}}$ & 5.33 & \\
\hline & & & 1 & & $69.6^{\mathrm{ab}}$ & $18.3^{\mathrm{ab}}$ & $9.18^{\mathrm{ab}}$ & 4.54 & \\
\hline \multirow[t]{4}{*}{ Broiler } & 1 & $\mathrm{Cec}$ & 0 & $\mu \mathrm{mol} / \mathrm{g}$ & $124^{b}$ & 29.3 & 22.0 & 6.70 & [27] \\
\hline & & & 0.25 & & $150^{a b}$ & 30.1 & 25 & 6.58 & \\
\hline & & & 0.5 & & $162^{a}$ & 32.8 & 26.1 & 6.36 & \\
\hline & & & 1 & & $129^{b}$ & 26 & 23.8 & 5.79 & \\
\hline \multirow[t]{3}{*}{ Broiler } & 1 & $\mathrm{Cec}$ & 0 & $\mu \mathrm{mol} / \mathrm{g}$ & 126 & 101 & 5.98 & $17.8^{\mathrm{a}}$ & [22] \\
\hline & & & $0.8^{4}$ & & 127 & 104 & 4.92 & $17.0^{\mathrm{a}}$ & \\
\hline & & & $0.8^{4}$ & & 119 & 99 & 5.28 & $13.1^{\mathrm{b}}$ & \\
\hline \multirow[t]{3}{*}{ Broiler } & 2 & $\mathrm{Cec}$ & 0 & $\mathrm{mmol} / \mathrm{L}$ & & 5.20 & 1.82 & 0.80 & {$[86]$} \\
\hline & & & 2 & & & 4.28 & 1.30 & 0.64 & \\
\hline & & & 4 & & & 4.09 & 1.50 & 0.58 & \\
\hline \multirow[t]{3}{*}{ Broiler } & 2 & $\mathrm{Cec}$ & 0.8 & $\mu \mathrm{mol} / \mathrm{g}$ & $56.8^{\mathrm{a}}$ & 38.1 & $8.89^{\mathrm{a}}$ & $8.45^{\mathrm{a}}$ & {$[25]$} \\
\hline & & & 5 & & $58.2^{\mathrm{a}}$ & 39.1 & $9.83^{\mathrm{a}}$ & $8.04^{\mathrm{a}}$ & \\
\hline & & & 10 & & $44.9^{b}$ & 33.9 & $4.82^{b}$ & $5.17^{\mathrm{b}}$ & \\
\hline \multirow[t]{3}{*}{ Laying hen } & 1 & $\mathrm{Cec}$ & 0 & $\mathrm{mmol} / 100 \mathrm{~g}$ & & $2.42^{\mathrm{b}}$ & $0.62^{b}$ & $0.19^{b}$ & [35] \\
\hline & & & 1 & & & $4.07^{\mathrm{a}}$ & $0.96^{\mathrm{a}}$ & $0.28^{\mathrm{a}}$ & \\
\hline & & & 2 & & & $3.01^{b}$ & $0.72^{b}$ & $0.20^{\mathrm{b}}$ & \\
\hline \multirow[t]{2}{*}{ Laying hen } & 1 & Cec & 0 & $\mu \mathrm{mol} / \mathrm{g}$ & $47.5^{\mathrm{a}}$ & $37.5^{\mathrm{a}}$ & $3.79^{\mathrm{a}}$ & 4.83 & [70] \\
\hline & & & 10 & & $29.2^{b}$ & $23.2^{\mathrm{b}}$ & $2.19^{b}$ & 2.89 & \\
\hline
\end{tabular}

${ }^{1}$ Feed formulation according to Fig. $1 ;{ }^{2}$ Intestinal part, lle = lleum, Cec $=$ Cecum; ${ }^{3}$ Information on the LC product used, if specified, is given in additional file $1 ;$ ${ }^{4}$ Two different lignocellulose products were compared; ${ }^{\mathrm{a}, \mathrm{b}, \mathrm{c}}$ Means with different superscripts are significantly different

of cecal SCFAs was not affected in broilers fed diets supplemented with $0.8 \%$ of the same LC product [22]. Moreover, LC-fed broilers had a lower cecal abundance of the bacteria families Ruminococcaceae and Lactobacillaceae as well as a higher abundance of Clostridiaceae, Enterobacteriaceae, Peptostreptococcaceae and Erysipelotrichaceae [22]. Diets diluted with $1 \%$ and $2 \%$ LC had in general no effect on detected bacteria except that counts of Ruminococcus spp. were increased and those of Clostridium spp. reduced in the cecum of broilers fed 2\% LC [24].

Based on the studies carried out so far, no uniform picture can be drawn as to whether and to what extent dietary LC influences the intestinal microbiota in chickens. It is generally agreed that insoluble fiber sources such as LC, cellulose or wood shavings, are not extensively degraded by intestinal bacteria residing in the avian digestive tract $[14,85,87]$. On the one hand, this is due to the anatomical peculiarities of the chicken's digestive tract, which is relatively short, resulting in a short feed passage rate. In addition, several studies suggest that only small and soluble fiber fractions can enter the cecum $[66,88,89]$, which appears to be the main site for bacterial fermentation of fiber in chickens [90, 91]. On the other hand, there is evidence that the cellulolytic activity of bacteria in the chicken's hindgut seems to be low [92-94]. Consequently, it is assumed that the impact of insoluble fiber on intestinal bacterial composition and activity appears to be minimal $[14,95]$. However, some authors speculated that LC could be fermented in the cecum of chickens as intestinal bacterial composition or SCFA profile had changed due to dietary LC inclusion $[22,27,35]$. Furthermore, some studies used an "eubiotic" LC product, which might have a higher susceptibility to microbial fermentation than the standard LC product [22, $35,86,96,97]$. Moreover, it was suggested that dietary LC may have an abrasive effect on the intestinal mucosa and adhering bacteria $[27,30]$ or that phenolic compounds of lignin exhibit antimicrobial properties [22, 27].

The major problem in answering the question of whether dietary insoluble fibers generally have an effect on the intestinal microbiota of chickens refers to the experimental diets chosen to study that effect. With reference to Fig. 1, most studies that investigated the effect of insoluble fiber on gut microbiota, chose experimental diets based on "feed formulation 1", and a few those based 
on "feed formulation 2". Depending on the amount of dietary fiber added, there are corresponding changes in the nutrient composition between the control and the fiber containing diet (Fig. 1). Alterations in the nutritional composition of the feed result in changes of the amount of substrate that reaches the large intestine and can be fermented by resident bacteria [25]. As a consequence, changes in the dietary nutrient composition may influence the gut microbiota and bacterial fermentation pathways [25], making it difficult to distinguish between nutrient composition- and fiber related effects. The best way to study the effect of insoluble fiber on gut microbiota is possibly to use feed variants according to "feed formulation 3" (Fig. 1). Feed and nutrient composition of control and fiber diets are very similar, although it cannot be ruled out that even the inclusion of an insoluble ash sources might affect the gut microbiota.

\section{Conclusions}

In conclusion, several studies were performed in order to evaluate the effect of dietary LC as an insoluble fiber source in poultry nutrition. Data on the impact of LC on growth performance, nutrient digestibility, digestive tract development and gut microbiota in chickens are inconsistent and do not allow a conclusive assessment. One of the reasons for this is that a direct comparison of results is difficult as studies differed in terms of feed formulations, LC inclusion levels and LC products. In future research, more attention should be paid to the type of feed formulation used in order to better distinguish the effects of dietary fiber from those of the feed and nutrient composition. In addition, the mode of action of LC in the digestive tract should be examined more closely, with particular reference to its chemical and physicochemical properties.

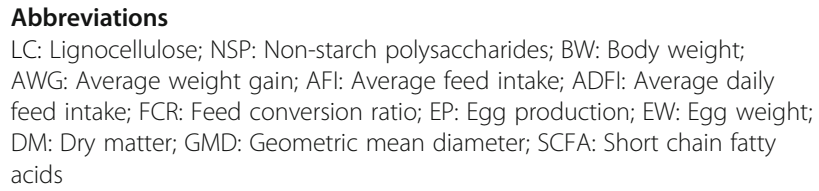

\section{Supplementary Information}

The online version contains supplementary material available at https://doi. org/10.1186/s40104-021-00594-y.

Additional file 1. Overview on LC products used in the different studies. Description of data: Additional information on LC used in the different studies including supplier information and product name.

\section{Acknowledgements}

Not applicable.

\section{Authors' contributions}

$\mathrm{IR}$ and JZ wrote and approved the manuscript.
Funding

Open Access funding enabled and organized by Projekt DEAL.

Availability of data and materials

Not applicable.

\section{Declarations}

Ethics approval and consent to participate

Not applicable.

\section{Consent for publication}

Not applicable.

\section{Competing interests}

The authors declare that we have no competing interests.

Received: 11 December 2020 Accepted: 11 April 2021

Published online: 17 June 2021

\section{References}

1. Hetland H, Svihus B, Choct M. Role of insoluble fiber on gizzard activity in layers. J Appl Poult Res. 2005;14(1):38-46. https://doi.org/10.1093/japr/14.1.38.

2. Montagne $L$, Pluske JR, Hampson DJ. A review of interactions between dietary fibre and the intestinal mucosa, and their consequences on digestive health in young non-ruminant animals. Anim Feed Sci Technol. 2003;108(1-4):95-117. https://doi.org/10.1016/S0377-8401(03)00163-9.

3. Mateos GG, Guzman P, Saldana B, Bonilla AP, Lazar R, Jimenez-Moreno E. Relevance of dietary fiber in poultry feeding. Proc ESPN PT7. 2013.

4. Kheravii SK, Morgan NK, Swick RA, Choct M, Wu S-B. Roles of dietary fibre and ingredient particle size in broiler nutrition. Worlds Poult Sci J. 2018; 74(2):301-16. https://doi.org/10.1017/S0043933918000259.

5. Zhou CH, Xia X, Lin C-X, Tong D-S, Beltramini J. Catalytic conversion of lignocellulosic biomass to fine chemicals and fuels. Chem Soc Rev. 2011; 40(11):5588-617. https://doi.org/10.1039/c1cs15124j.

6. Kröger S, Vahjen W, Zentek J. Influence of lignocellulose and low or high levels of sugar beet pulp on nutrient digestibility and the fecal microbiota in dogs. J Anim Sci. 2017;95(4):1598-605. https://doi.org/10.2527/jas.2016. 0873 .

7. Abad R, Ibáñez MA, Carabaño R, García J. Quantification of soluble fibre in feedstuffs for rabbits and evaluation of the interference between the determinations of soluble fibre and intestinal mucin. Anim Feed Sci Technol. 2013;182(1-4):61-70. https://doi.org/10.1016/j.anifeedsci.2013.04. 001.

8. Vervuert I, Klein S, Coenen M. Effect of mixing dietary fibre (purified lignocellulose or purified pectin) and a corn meal on glucose and insulin responses in healthy horses. J Anim Physiol Anim Nutr. 2009;93(3):331-8. https://doi.org/10.1111/j.1439-0396.2008.00846.x.

9. Slama J, Schedle K, Wetscherek W, Pekar D, Schwarz C, Gierus M. Effects of soybean hulls and lignocellulose on performance, nutrient digestibility, microbial metabolites and immune response in piglets. Arch Anim Nutr. 2020:74:1-16.

10. Pieper R, Boudry C, Bindelle J, Vahjen W, Zentek J. Interaction between dietary protein content and the source of carbohydrates along the gastrointestinal tract of weaned piglets. Arch Anim Nutr. 2014;68(4):263-80. https://doi.org/10.1080/1745039X.2014.932962

11. Theander O, Åman P, Westerlund E, Graham H. Enzymatic/chemical analysis of dietary fiber. J AOAC Int. 1994;77(3):703-9. https://doi.org/10.1093/jaoac/ 77.3.703.

12. Trowell H, Southgate DAT, Wolever TMS, Leeds AR, Gassull MA, Jenkins DJA Dietary fibre redefined. Lancet. 1976;1:967.

13. Bach Knudsen KEB. The nutritional significance of "dietary fibre" analysis. Anim Feed Sci Technol. 2001;90(1-2):3-20. https://doi.org/10.1016/S0377-84 01(01)00193-6.

14. Hetland $\mathrm{H}$, Choct $\mathrm{M}$, Svihus B. Role of insoluble non-starch polysaccharides in poultry nutrition. World's Poult Sci J. 2004;60(4):415-22. https://doi.org/1 0.1079 /WPS200325.

15. Collard F-X, Blin J. A review on pyrolysis of biomass constituents: mechanisms and composition of the products obtained from the conversion of cellulose, hemicelluloses and lignin. Renew Sust Energ Rev. 2014;38:594-608. https://doi.org/10.1016/j.rser.2014.06.013. 
16. Liu C, Wang H, Karim AM, Sun J, Wang Y. Catalytic fast pyrolysis of lignocellulosic biomass. Chem Soc Rev. 2014;43(22):7594-623. https://doi. org/10.1039/C3CS60414D.

17. Isikgor FH, Becer CR. Lignocellulosic biomass: a sustainable platform for the production of bio-based chemicals and polymers. Polym Chem. 2015;6(25): 4497-559. https://doi.org/10.1039/C5PY00263J.

18. Cai J, He Y, Yu X, Banks SW, Yang Y, Zhang X, et al. Review of physicochemical properties and analytical characterization of lignocellulosic biomass. Renew Sust Energ Rev. 2017;76:309-22. https://doi.org/10.1016/j. rser.2017.03.072

19. Slama J, Schedle K, Wurzer GK, Gierus M. Physicochemical properties to support fibre characterization in monogastric animal nutrition. J Sci Food Agric. 2019;99(8):3895-902. https://doi.org/10.1002/jsfa.9612.

20. Jiménez-Moreno E, Frikha M, de Coca-Sinova A, García J, Mateos GG. Oat hulls and sugar beet pulp in diets for broilers 1. Effects on growth performance and nutrient digestibility. Anim Feed Sci Technol. 2013;182(1 4):33-43. https://doi.org/10.1016/j.anifeedsci.2013.03.011.

21. Choct M. 2015. Fibre-Chemistry and functions in poultry nutrition. LII Simposio Científico de Avicultura, Málaga, 28 al 30 de octubre: 113-119. https://www.wpsa-aeca.es/aeca_imgs_docs/16478_fibra_mingan.pdf.

22. Zeitz JO, Neufeld K, Potthast C, Kroismayr A, Most E, Eder K. Effects of dietary supplementation of the lignocelluloses FibreCell and OptiCell on performance, expression of inflammation-related genes and the gut microbiome of broilers. Poult Sci. 2019;98(1):287-97. https://doi.org/10.3382/ ps/pey345.

23. Mateos GG, Jiménez-Moreno E, Serrano MP, Lázaro RP. Poultry response to high levels of dietary fiber sources varying in physical and chemical characteristics. J Appl Poult Res. 2012;21(1):156-74. https://doi.org/10.3382/ja pr.2011-00477.

24. Kheravii SK, Swick RA, Choct M, Wu SB. Coarse particle inclusion and lignocellulose-rich fiber addition in feed benefit performance and health of broiler chickens. Poult Sci. 2017;96(9):3272-81. https://doi.org/10.3382/ps/ pex123.

25. Röhe I, Metzger F, Vahjen W, Brockmann GA, Zentek J. Effect of feeding different levels of lignocellulose on performance, nutrient digestibility, excreta dry matter, and intestinal microbiota in slow growing broilers. Poult Sci. 2020;99(10):5018-26. https://doi.org/10.1016/j.psj.2020.06.053.

26. Sarikhan M, Shahryar HA, Gholizadeh B, Hosseinzadeh MH, Beheshti B, Mahmoodnejad A. Effects of insoluble fiber on growth performance, carcass traits and ileum morphological parameters on broiler chick males. Int J Agric Biol. 2010;12:531-6.

27. Bogusławska-Tryk M, Szymeczko R, Piotrowska A, Burlikowska K, Śliżewska K. Ileal and cecal microbial population and short-chain fatty acid profile in broiler chickens fed diets supplemented with lignocellulose. Pak Vet J. 2015 35:212-6.

28. Rahmatnejad E, Saki AA. Effect of dietary fibres on small intestine histomorphology and lipid metabolism in young broiler chickens. J Anim Physiol Anim Nutr. 2016;100(4):665-72. https://doi.org/10.1111/.jpn.12422.

29. Abdollahi MR, Zaefarian F, Hunt H, Anwar MN, Thomas DG, Ravindran V. Wheat particle size, insoluble fibre sources and whole wheat feeding influence gizzard musculature and nutrient utilisation to different extents in broiler chickens. J Anim Physiol Anim Nutr. 2019;103(1):146-61. https://doi. org/10.1111/jpn.13019.

30. Makivic L, Glisic M, Boskovic M, Djordjevic J, Markovic R, Baltic M, et al. Performances, ileal and cecal microbial populations and histological characteristics in broilers fed diets supplemented with lignocellulose. Kafkas Univ Vet Fak Derg. 2019:25:83-91.

31. Oikeh I, Sakkas P, Taylor J, Giannenas I, Blake DP, Kyriazakis I. Effects of reducing growth rate via diet dilution on bone mineralization, performance and carcass yield of coccidia-infected broilers. Poult Sci. 2019;98(11):547787. https://doi.org/10.3382/ps/pez400

32. Sozcu A. Growth performance, pH value of gizzard, hepatic enzyme activity, immunologic indicators, intestinal histomorphology, and cecal microflora of broilers fed diets supplemented with processed lignocellulose. Poult Sci. 2019;98(12):6880-7. https://doi.org/10.3382/ps/pez449.

33. Miloševic N, Dukić Strojćić $M$, Perić L, Vukić-Vranješ M. Effect of lignocellulose on egg production and egg quality. 20th. Eur Symp Poult Nutr. 2015:2015:24-7 Prague:158.

34. Yokhana JS, Parkinson G, Frankel TL. Effect of insoluble fiber supplementation applied at different ages on digestive organ weight and digestive enzymes of layer-strain poultry. Poult Sci. 2015;95:550-9.
35. Sun B, Hou L, Yang Y. Effects of Eubiotic lignocellulose on the gut microbiota and metabolism of chickens. Research Square. 2020. https://doi. org/10.21203/rs.3.rs-49629/v1.

36. Sozcu A, Ipek A. The effects of lignocellulose supplementation on laying performance, egg quality parameters, aerobic bacterial load of eggshell, serum biochemical parameters, and jejunal histomorphological traits of laying hens. Poult Sci. 2020;99(6):3179-87. https://doi.org/10.1016/j.psj.2020. 01.024 .

37. Mohiti-Asli M, Shivazad M, Zaghari M, Rezaian M, Aminzadeh S, Mateos GG. Effects of feeding regimen, fiber inclusion, and crude protein content of the diet on performance and egg quality and hatchability of eggs of broiler breeder hens. Poult Sci. 2012;91(12):3097-106. https://doi.org/10.3382/ps.2 012-02282.

38. Röhe I, Urban J, Dijkslag A, te Paske J, Zentek J. Impact of an energy-and nutrient-reduced diet containing 10\% lignocellulose on animal performance, body composition and egg quality of dual purpose laying hens. Arch Anim Nutr. 2019;73(1):1-17. https://doi.org/10.1080/1745039X.201 8.1551950 .

39. Nassar MK, Lyu S, Zentek J, Brockmann GA. Dietary fiber content affects growth, body composition, and feed intake and their associations with a major growth locus in growing male chickens of an advanced intercross population. Livest Sci. 2019;227:135-42. https://doi.org/10.1016/j.livsci.2019.07.015.

40. Rizzi C, Chiericato GM. Chemical composition of meat and egg yolk of hybrid and Italian breed hens reared using an organic production system. Poult Sci. 2010;89(6):1239-51. https://doi.org/10.3382/ps.2008-00045.

41. Liu Z-C, Su C-M, Xie Y-L, Chang C-J, Chen J-Y, Wu S-W, et al. Intracellular lipid dysregulation interferes with leukocyte function in the ovaries of meattype hens under unrestricted feed intake. Anim Reprod Sci. 2016;167:40-50. https://doi.org/10.1016/j.anireprosci.2016.02.002.

42. Chen SE, McMurtry JP, Walzem RL. Overfeeding-induced ovarian dysfunction in broiler breeder hens is associated with lipotoxicity. Poult Sci. 2006;85(1):70-81. https://doi.org/10.1093/ps/85.1.70.

43. Amerah AM, Ravindran V, Lentle RG. Influence of insoluble fibre and whole wheat inclusion on the performance, digestive tract development and ileal microbiota profile of broiler chickens. Br Poult Sci. 2009;50(3):366-75. https://doi.org/10.1080/00071660902865901.

44. Shakouri MD, Kermanshahi H, Mohsenzadeh M. Effect of different non starch polysaccharides in semi purified diets on performance and intestinal microflora of young broiler chickens. International J Poult Sci. 2006;5:557-61.

45. Panda JN, Combs GF. Studies on the energy requirement of the chick for rapid growth. Poult Sci. 1950;29:774-5.

46. Hill FW, Dansky LM. Studies of the energy requirements of chickens: 1. The effect of dietary energy level on growth and feed comsumption. Poult Sci. 1954;33(1):112-9. https://doi.org/10.3382/ps.0330112.

47. Fisher $\mathrm{H}$, Weiss HS. Feed consumption in relation to dietary bulk and energy level: the effect of surgical removal of the crop. Poult Sci. 1956;35(2):418-23. https://doi.org/10.3382/ps.0350418.

48. Leeson S, Caston L, Summers JD. Broiler response to energy or energy and protein dilution in the finisher diet. Poult Sci. 1996;75(4):522-8. https://doi. org/10.3382/ps.0750522.

49. Van Krimpen MM, Kwakkel RP, Van der Peet-Schwering CMC, Den Hartog LA, Verstegen MWA. Effects of nutrient dilution and nonstarch polysaccharide concentration in rearing and laying diets on eating behavior and feather damage of rearing and laying hens. Poult Sci. 2009;88(4):75973. https://doi.org/10.3382/ps.2008-00194.

50. Van Krimpen MM, Kwakkel RP, André G, Van Der Peet-Schwering CMC, Den Hartog LA, Verstegen MWA. Effect of nutrient dilution on feed intake, eating time and performance of hens in early lay. Bri Poult Sci. 2007;48(4):389-98. https://doi.org/10.1080/00071660701509619.

51. Farran MT, Akilian HA, Hamoud AM, Barbour GW, Saoud IP. Lignocellulose improves protein and amino acid digestibility in roosters and egg hatchability in broiler breeders. J Poult Sci. 2017;54(3):197-204. https://doi. org/10.2141/jpsa.0160095.

52. Farran MT, Pietsch $M$, Chabrillat T. Effect of lignocellulose on the litter quality and the ready to cook carcass yield of male broilers. Actes des 10èmes Journées de la Recherche Avicole et Palmipèdes à Foie Gras du 26 au 28 mars, 2013, La Rochelle, France; 2013. p. 917-21.

53. Bogusławska-Tryk M, Piotrowska A, Szymeczko R, Burlikowska K. Effect of dietary lignocellulose on ileal and total tract digestibility of fat and fatty acids in broiler chickens. J Anim Physiol Anim Nutr. 2016;100(6):1050-7. https://doi.org/10.1111/jpn.12476. 
54. Svihus B. The gizzard: function, influence of diet structure and effects on nutrient availability. Worlds Poult Sci J. 2011;67(2):207-24. https://doi.org/1 $0.1017 /$ S0043933911000249.

55. Jiménez-Moreno E, González-Alvarado JM, González-Sánchez D, Lázaro R, Mateos GG. Effects of type and particle size of dietary fiber on growth performance and digestive traits of broilers from 1 to 21 days of age. Poult Sci. 2010;89(10):2197-212. https://doi.org/10.3382/ps.2010-00771.

56. Kluth $\mathrm{H}$, Rodehutscord $\mathrm{M}$. Effect of inclusion of cellulose in the diet on the inevitable endogenous amino acid losses in the ileum of broiler chicken. Poult Sci. 2009;88(6):1199-205. https://doi.org/10.3382/ps.2008-00385.

57. Rezaei M, Torshizi MAK, Shariatmadari F. Inclusion of processed rice hulls as insoluble fiber in the diet on performance and digestive traits of Japanese quails. J Anim Sci Adv. 2014;4(7):962-72. https://doi.org/10.5455/jasa.2014 0724124546

58. Hetland H, Svihus B, Krogdahl $\AA$. Effects of oat hulls and wood shavings on digestion in broilers and layers fed diets based on whole or ground wheat. Br Poult Sci. 2003;44(2):275-82. https://doi.org/10.1 080/0007166031000124595.

59. González-Alvarado JM, Jiménez-Moreno E, Lázaro R, Mateos GG. Effect of type of cereal, heat processing of the cereal, and inclusion of fiber in the diet on productive performance and digestive traits of broilers. Poult Sci. 2007;86(8):1705-15. https://doi.org/10.1093/ps/86.8.1705.

60. Roche M. Feeding behaviour and digestive motility of birds. Reprod Nutr Dev. 1981;21(5B):781-8. https://doi.org/10.1051/rnd:19810611.

61. Jiménez-Moreno E, González-Alvarado JM, González-Serrano A, Lázaro R, Mateos GG. Effect of dietary fiber and fat on performance and digestive traits of broilers from one to twenty-one days of age. Poult Sci. 2009;88(12): 2562-74. https://doi.org/10.3382/ps.2009-00179.

62. Kimiaeitalab MV, Cámara L, Goudarzi SM, Jiménez-Moreno E, Mateos GG. Effects of the inclusion of sunflower hulls in the diet on growth performance and digestive tract traits of broilers and pullets fed a broiler diet from zero to $21 \mathrm{~d}$ of age. A comparative study. Poult Sci. 2017:96(3): 581-92. https://doi.org/10.3382/ps/pew263.

63. Jiménez-Moreno E, Chamorro S, Frikha M, Safaa HM, Lázaro R, Mateos GG. Effects of increasing levels of pea hulls in the diet on productive performance, development of the gastrointestinal tract, and nutrient retention of broilers from one to eighteen days of age. Anim Feed Sci Technol. 2011;168(1-2):10012. https://doi.org/10.1016/j.anifeedsci.2011.03.013.

64. Li Y, Owyang C. Vagal afferent pathway mediates physiological action of cholecystokinin on pancreatic enzyme secretion. J Clin Invest. 1993;92(1): 418-24. https://doi.org/10.1172/JCl116583.

65. Gabriel I, Mallet S, Leconte M, Travel A, Lalles J. Effects of whole wheat feeding on the development of the digestive tract of broiler chickens. Anim Feed Sci Technol. 2007;142:144-62.

66. Rougière N, Gomez J, Mignon-Grasteau S, Carré B. Effects of diet particle size on digestive parameters in D+ and D- genetic chicken lines selected for divergent digestion efficiency. Poult Sci. 2009;88(6):1206-15. https://doi. org/10.3382/ps.2008-00408

67. Svihus $B$, Juvik $E$, Hetland $H$, Krogdahl A. Causes for improvement in nutritive value of broiler chicken diets with whole wheat instead of ground wheat. Br Poult Sci. 2004;45(1):55-60. https://doi.org/10.1080/0007166041 0001668860

68. Svihus B, Klovstad K, Perez V, Zimonja O, Sahlstrom S, Schuller R, et al. Physical and nutritional effects of pelleting of broiler chicken diets made from wheat ground to different coarsenesses by the use of roller mill and hammer mill. Anim Feed Sci Technol. 2004;117(3-4):281-93. https://doi.org/1 0.1016/j.anifeedsci.2004.08.009.

69. Bogusławska-Tryk M, Bogucka J, Dankowiakowska A, Walasik K. Smal intestine morphology and ileal biogenic amines content in broiler chickens fed diets supplemented with lignocellulose. Livest Sci. 2020;241:104189. https://doi.org/10.1016/j.livsci.2020.104189.

70. Röhe I, Vahjen W, Metzger F, Zentek J. Effect of a "diluted" diet containing $10 \%$ lignocellulose on the gastrointestinal tract, intestinal microbiota, and excreta characteristics of dual purpose laying hens. Poult Sci. 2020;99(1): 310-9. https://doi.org/10.3382/ps/pez492.

71. Uni Z, Tako E, Gal-Garber O, Sklan D. Morphological, molecular, and functional changes in the chicken small intestine of the late-term embryo. Poult Sci. 2003:82(11):1747-54. https://doi.org/10.1093/ps/82.11.1747.

72. Jiménez-Moreno E, Frikha M, de Coca-Sinova A, Lázaro R, Mateos GG. Oat hulls and sugar beet pulp in diets for broilers. 2. Effects on the development of the gastrointestinal tract and on the structure of the jejunal mucosa. Anim Feed Sci and Technol. 2013;182(1-4):44-52. https://doi.org/1 0.1016/j.anifeedsci.2013.03.012

73. González-Alvarado JM, Jiménez-Moreno E, González-Sánchez D, Lázaro R, Mateos GG. Effect of inclusion of oat hulls and sugar beet pulp in the diet on productive performance and digestive traits of broilers from 1 to 42 days of age. Anim Feed Sci Technol. 2010;162(1-2):37-46. https://doi.org/1 0.1016/j.anifeedsci.2010.08.010.

74. Sklan D, Smirnov A, Plavnik I. The effect of dietary fibre on the small intestines and apparent digestion in the Turkey. Br Poult Sci. 2003;44(5):73540. https://doi.org/10.1080/00071660310001643750.

75. González-Alvarado JM, Jiménez-Moreno E, Valencia DG, Lázaro R, Mateos GG. Effects of fiber source and heat processing of the cereal on the development and $\mathrm{pH}$ of the gastrointestinal tract of broilers fed diets based on corn or rice. Poult Sci. 2008;87(9):1779-95. https://doi.org/10.3382/ps.2 008-00070.

76. Jiménez-Moreno E, González-Alvarado JM, de Coca-Sinova A, Lázaro R, Mateos GG. Effects of source of fibre on the development and $\mathrm{pH}$ of the gastrointestinal tract of broilers. Anim Feed Sci Technol. 2009;154(1-2):93101. https://doi.org/10.1016/j.anifeedsci.2009.06.020.

77. Hetland H, Svihus B. Effect of oat hulls on performance, gut capacity and feed passage time in broiler chickens. Br Poult Sci. 2001:42(3):354-61. https://doi.org/10.1080/00071660120055331.

78. Svihus $B$, Hetland $H$. Ileal starch digestibility in growing broiler chickens fed on a wheat-based diet is improved by mash feeding, dilution with cellulose or whole wheat inclusion. Br Poult Sci. 2001;42(5):633-7. https://doi.org/10.1 080/00071660120088461.

79. Röhe I, Göbel TW, Goodarzi Boroojeni FG, Zentek J. Effect of feeding soybean meal and differently processed peas on the gut mucosal immune system of broilers. Poult Sci. 2017;96(7):2064-73. https://doi.org/10.3382/ps/ pew491.

80. Iji PA, Saki AA, Tivey DR. Intestinal development and body growth of broiler chicks on diets supplemented with non-starch polysaccharides. Anim Feed Sci Technol. 2001;89(3-4):175-88. https://doi.org/10.1016/S0377-8401 (00)00223-6.

81. Yamauchi K. Review of a histological intestinal approach to assessing the intestinal function in chickens and pigs. Anim Sci J. 2007;78(4):356-70. https://doi.org/10.1111/j.1740-0929.2007.00448.x.

82. Bedford M. Removal of antibiotic growth promoters from poultry diets: implications and strategies to minimise subsequent problems. Worlds Poult Sci J. 2000;56(4):347-65. https://doi.org/10.1079/WPS20000024.

83. Brenes A, Smith M, Guenter W, Marquardt RR. Effect of enzyme supplementation on the performance and digestive tract size of broiler chickens fed wheat-and barley-based diets. Poult Sci. 1993;72(9):1731-9. https://doi.org/10.3382/ps.0721731.

84. Makki K, Deehan EC, Walter J, Bäckhed F. The impact of dietary fiber on gut microbiota in host health and disease. Cell Host Microbe. 2018;23(6):705-15. https://doi.org/10.1016/j.chom.2018.05.012.

85. Jha R, Fouhse JM, Tiwari UP, Li L, Willing BP. Dietary fiber and intestinal health of monogastric animals. Front Vet Sci. 2019;6:48. https://doi.org/10.33 89/fvets.2019.00048

86. Hou L, Sun B, Yang Y. Effects of added dietary Fiber and rearing system on the gut microbial diversity and gut health of chickens. Animals. 2020;10(1): 107. https://doi.org/10.3390/ani10010107.

87. Choct M, Hughes RJ, Wang J, Bedford MR, Morgan AJ, Annison G. Increased small intestinal fermentation is partly responsible for the anti-nutritive activity of non-starch polysaccharides in chickens. Br Poult Sci. 1996;37(3): 609-21. https://doi.org/10.1080/00071669608417891.

88. Bjornhag G, Sperber I. Transport of various food components through the digestive tract of turkeys, geese and Guinea fowl. Swed J Agric Res. 1977:7:57-66.

89. Vergara P, Ferrando C, Jiménez M, Fernández E, Goñalons E. Factors determining gastrointestinal transit time of several markers in the domestic fowl. Q J Exp Physiol. 1989;74(6):867-74. https://doi.org/10.1113/expphysiol.1 989.sp003357.

90. Józefiak D, Rutkowski A, Martin SA. Carbohydrate fermentation in the avian ceca: a review. Anim Feed Sci Technol. 2004;113(1-4):1-15. https://doi.org/1 0.1016/j.anifeedsci.2003.09.007.

91. Clench MH, Mathias JR. The avian cecum: a review. Wilson Ornithol Soc. 1995;107:93-121.

92. McNab JM. The avian caeca: a review. Worlds Poult Sci J. 1973:29(3):251-63. https://doi.org/10.1079/WPS19730014. 
93. Mead GC. Microbes of the avian cecum: types present and substrates utilized. J Exp Zool. 1989;252(S3):48-54. https://doi.org/10.1002/jez.140252 0508.

94. Waite DW, Taylor MW. Characterizing the avian gut microbiota: membership, driving influences, and potential function. Front Microbiol. 2014;5:223.

95. Walugembe M, Hsieh JCF, Koszewski NJ, Lamont SJ, Persia ME, Rothschild MF. Effects of dietary fiber on cecal short-chain fatty acid and cecal microbiota of broiler and laying-hen chicks. Poult Sci. 2015;94(10):2351-9. https://doi.org/10.3382/ps/pev242.

96. Kroismayr A. Choosing the right fibre for poultry-eubiotic lignocellulose. Mort. 2014;7:26.20.

97. Youssef IMI, Kamphues J. Fermentation of fibre rich ingredients exposed in vitro to the faecal inoculums of swine and turkeys. Vet Med Sci. 2020;6(3): 511-7. https://doi.org/10.1002/vms3.252

Ready to submit your research? Choose BMC and benefit from:

- fast, convenient online submission

- thorough peer review by experienced researchers in your field

- rapid publication on acceptance

- support for research data, including large and complex data types

- gold Open Access which fosters wider collaboration and increased citations

- maximum visibility for your research: over $100 \mathrm{M}$ website views per year

At $\mathrm{BMC}$, research is always in progress.

Learn more biomedcentral.com/submissions 